\title{
Ketuntasan Belajar Matematika Masa Pandemi Covid-19 Program Televisi Edukasi Belajar dari Rumah
}

\author{
Lutfiyah $^{1)}$ \\ ${ }^{1)}$ IKIP PGRI Jember \\ Email: azkalutfimh@gmail.com
}

\begin{abstract}
One of the government policies during the Covid-19 pandemic in the field of education is that students continue to learn from their respective homes, one of which is educational television provided on the TVRI channel in the form of a home learning educational program. This research discusses the completeness of learning mathematics with the aim of knowing the completeness of learning mathematics during the Covid-19 pandemic educational television program learning from home in achieving the minimum completeness standard according to the provisions of the Education Office. This type of research is descriptive, the subjects in this study were VIII grade students of Madrasah Tsanawiyah. Data collection techniques were used by observation and interviews. The results of the study, the first daily score with the student's incomplete comparison material was $8 \%$ while those who completed were $92 \%$, the second daily value analysis using the Phytagoras theorem material was $12 \%$ while those who completed $88 \%$, the third daily value analysis with material Social arithmetic of students who did not complete was $12 \%$ while those who completed were $88 \%$, analysis of the fourth daily value with the material of the incomplete student circle as much as $8 \%$ which was complete $92 \%$, the analysis of the fifth daily score with the incomplete $12 \%$ which was complete $88 \%$, the analysis of the sixth daily value with the material of the curved side of the building of students who did not complete $16 \%$ while those who were complete $84 \%$ could be concluded that learning with TVRI education television students' learning completeness in the first to fifth assessments had reached the minimum completeness criteria, while in the assessment sixth has not reached the minimum completeness criteria.
\end{abstract}

Keywords : Completeness of Learning, Pandemic, Educational Television, Learning From Home

\begin{abstract}
ABSTRAK
Kebijakan pemerintah masa pandemi Covid-19 dibidang pendidikan salah satunya adalah siswa tetap belajar dari rumah masing-masing, televisi edukasi yang
\end{abstract}


disediakan salah satunya pada channel TVRI berupa program edukasi belajar dari rumah. Penelitian ini membahas ketuntasan belajar matematika dengan tujuan untuk mengetahui ketuntasan belajar matematika masa pandemi Covid-19 program televisi edukasi belajar dari rumah dalam mencapai standar ketuntasan minimal sesuai ketentuan Dinas Pendidikan. Jenis penelitian deskriptif, subjek dalam penelitian ini siswa Madrasah Tsanawiyah kelas VIII, teknik pengumpulan data dengan cara observasi dan wawancara. Hasil penelitian, nilai harian pertama dengan materi perbandingan siswa yang tidak tuntas sebanyak $8 \%$ sedangkan yang tuntas sebanyak 92\%, analisa nilai harian kedua dengan materi teorema Phytagoras siswa yang tidak tuntas sebanyak $12 \%$ sedangkan yang tuntas $88 \%$, analisa nilai harian ketiga dengan materi aritmatika sosial siswa yang tidak tuntas sebanyak $12 \%$ sedangkan yang tuntas sebanyak $88 \%$, analisa nilai harian keempat dengan materi lingkaran siswa yang tidak tuntas sebanyak $8 \%$ yang tuntas $92 \%$, analisa nilai harian kelima dengan materi pecahan siswa yang tidak tuntas $12 \%$ yang tuntas $88 \%$, analisa nilai harian keenam dengan materi bangun ruang sisi lengkung siswa yang tidak tuntas $16 \%$ sedangkan yang tuntas $84 \%$ dapat disimpulkan bahwa pembelajaran dengan televisi edukasi TVRI ketuntasan belajar siswa pada penilaian pertama sampai penilaian kelima sudah mencapai kriteria ketuntasan minimal, sedangkan pada penilaian keenam belum mencapai kriteria ketuntasan minimum.

Kata Kunci : Ketuntasan Belajar, Pandemi, Televisi Edukasi, Belajar dari Rumah

\section{PENDAHULUAN}

Kebijakan penanggulangan wabah penyakit menular, pemerintah telah memiliki Peraturan nomor 40 tahun 1991, untuk penanggulangan dini wabah Covid19 Menteri Kesehatan Republik Indonesia mengeluarkan keputusan nomor HK.01.07/MENKES/413/2020 tentang pedoman pencegahan dan pengendalian Covid-19, Dalam rangka menanggulangi pandemi Covid-19 Indonesia menerapkan salah satu langkah kesehatan masyarakat termasuk pembatasan sosial berskala besar (PSBB) dimana salah satunya penutupan sekolah. Surat edaran nomor 4 tahun 2020 tentang pelaksanaan kebijakan pendidikan dalam masa darurat penyebaran Covid-19 maka kesehatan guru, siswa dan seluruh warga sekolah menjadi pertimbangan, sehingga proses pembelajaran di sekolah digantikan dengan proses belajar dari rumah, proses tersebut merupakan solusi yang dilakukan oleh Menteri Pendidikan dan Kebudayaan Republik Indonesia, ketentuan belajar dari rumah melalui pembelajaran daring/jarak jauh dilaksanakan untuk memberikan pengalaman belajar yang bermakna bagi siswa, tanpa terbebani tuntutan menuntaskan seluruh capaian kurikulum untuk kenaikan kelas maupun kelulusan. 
Perlu disadari bahwa guru dan siswa belum ada kesiapan untuk melakukan pembelajaran daring, kondisi yang mengharuskan perubahan terjadi dari proses pembelajaran konvensional menjadi proses pembelajaran daring, tanpa adanya persiapan yang matang, pembelajaran daring tetap harus dilakukan agar proses belajar pada siswa tidak terhenti dalam kondisi pandemi Covid-19 (Masdafni 2020, Asmuni 2020).

Himbauan pemerintah pada semua jenjang pendidikan yang berada di Indonesia dalam masa pandemi Covid-19 bahwa proses belajar dilakukan dari rumah, sehingga proses belajar mengajar pada tahun 2020 ini tidak seperti biasanya ada sedikit perbedaan dari tahun-tahun sebelumnya, dimana proses pembelajaran yang dilakukan saat pandemi Covid-19 menggunakan pembelajaran daring untuk membatasi aktivitas diluar rumah yang menyebabkan terjadi kerumunan banyak siswa, awal terjadi pandemi memaksakan semua lembaga pendidikan dari setiap jenjang untuk melakukan pembelajaran daring, sehingga salah satu solusi yang diberikan oleh menteri pendidikan yaitu televisi edukasi pada channel TVRI agar siswa tetap belajar, diawal pandemi rata-rata setiap sekolah belum memiliki kesiapan untuk belajar daring, maka program televisi edukasi merupakan solusi yang diambil oleh beberapa sekolah, terutama sekolah yang berada dilingkungan pedesaan dengan berbagai kendala dan keterbatasan diantaranya keterbatsan pada jaringan internet oleh masing-masing siswa serta keterbatasan benda elektronik pendukung pembelajaran.

Pembelajaran matematika pada siswa dalam program televisi edukasi TVRI, menampilkan pembelajaran lebih menarik daripada sekedar metode ceramah yang masih dilakukan oleh beberapa pendidik disekolah, pada televisi edukasi pembelajaran matematika selain menampilkan konsep juga diberikan contoh yang berkaitan dengan kehidupan sehari-hari agar siswa tidak merasa bosan, selain contoh ada juga latihan yang harus dikerjakan disetiap akhir pembelajaran, sebagai bahan evaluasi oleh guru terhadap siswa dalam mengetahui pemahaman konsep yang telah disampaikan. Kendala yang terjadi selama melaksanakan proses pembelajaran daring, jadikanlah tantangan bagi para pendidik dalam mentransformasikan pendidikan pada siswa agar lebih maju (Wiryanto, 2020).

Dalam mengetahui pemahaman siswa, guru tetap menggunakan standar kriteria ketuntasan minimal dari dinas pendidikan untuk setiap jenjang pada sekolah 
yang merupakan pegangan yang harus dimiliki oleh setiap guru, agar memiliki gambaran terkait ketuntasan belajar yang dimiliki oleh siswanya.

Beberapa penelitian sebelumnya bahwa pembelajaran daring dapat meningkatkan hasil belajar siswa mencapai prosentase ketuntasan minimum dengan aplikasi Google Classroom selama pandemi (Ratnawati, F.A, 2020), selain itu penelitian terkait mengatakan ada beberapa aspek yang meragukan penggunaan media edutainment dalam pembelajaran matematika, sehingga perlu adanya teknologi yang mendukung untuk menjadikan media pembealajaran yang paling efektif dalam mencapai ketuntasan belajar (Pratama L.D. dkk, 2020). Tujuan dari penelitian ini untuk mengetahui ketuntasan belajar matematika masa pandemi Covid-19 program televisi edukasi belajar dari rumah.

\section{METODE PENELITIAN}

Jenis penelitian deskriptif kualitatif, dimana penelitian ini akan menyajikan secara deskripsi ketuntasan hasil belajar matematika berupa nilai siswa dengan cara belajar menggunakan media televisi pada program televisi edukasi TVRI belajar dari rumah pada masa pandemi, rekap nilai akan diambil dari beberapa nilai harian guru yang akan di analisa ketuntasan belajarnya berdasarkan standar kriteria ketuntasan minimal sekolah yang sudah ditentukan oleh dinas pendidikan kabupaten. Subjek penelitian siswa Madrasah Tsanawiyah Raden Rahmat Umbulsari Kabupaten Jember.

Teknik pengumpulan data dengan observasi dan wawancara, observasi dilakukan untuk memperoleh data berupa nilai siswa selama pembelajaran menggunakan program televisi edukasi TVRI, wawancara dilakukan dua kali yaitu wawancara 1 dilakukan untuk mendapatkan informasi pelaksanaan pembelajaran pada saat pandemi serta KKM sekolah yang harus dicapai pada pembelajaran matematika, dan wawancara 2 dilakukan untuk mendapatkan informasi lebih lanjut terkait hasil belajar siswa serta untuk mendapatkan langkah berikutnya yang akan dilakukan oleh guru dalam pembelajaran matematika saat pandemi belum berakhir.

Analisa data model Miles and Huberman, analisa data dilakukan pada saat pengumpulan data berlangsung dan setelah selesai pengumpulan data dalam periode tertentu (Sugiyono, 2014). Aktivitas dalam analisa data yaitu dengan cara yang 
pertama reduksi data kedua display data ketiga kesimpulan/verifikasi. Dengan langkah analisa pada gambar di bawah ini.

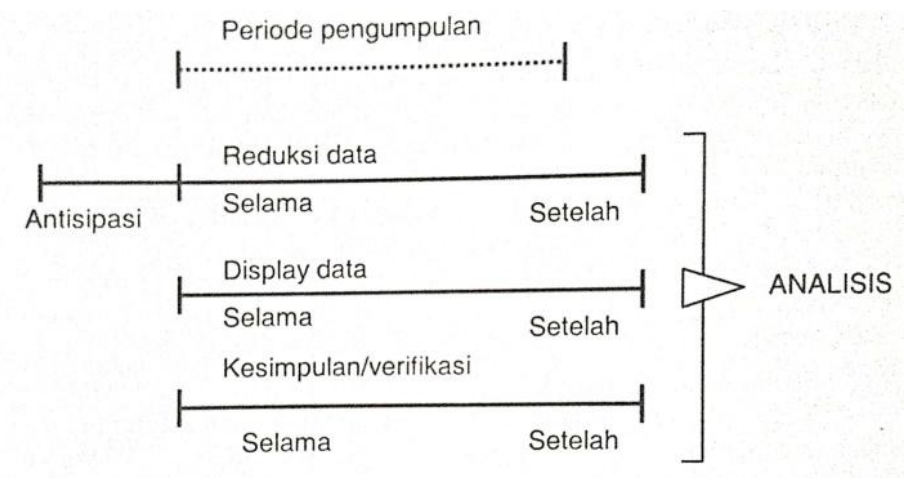

Gambar 1. Analisa Data Flow Model (Sugiyono, 2014)

\section{HASIL DAN PEMBAHASAN}

Awal terjadinya wabah menular yang terjadi di Indonesia, pemerintah menghimbau untuk melibur seluruh siswa selama beberapa hari, setelah itu adanya himbauan kembali bagi siswa selama belum berakhirnya wabah menular untuk tetap belajar dari rumah, sehingga beberapa sekolah membuat pertimbangan untuk melakukan teknik pembelajaran daring yang telah dihimbau oleh menteri pendidikan. Hasil wawancara 1 dengan guru matematika, terkait teknik pembelajaran yang diambil dalam masa awal pandemi dengan adanya kebijakan dari menteri pendidikan bahwa siswa belajar dari rumah, dimana pertimbangan yang diambil oleh guru Madrasah Tsanawiyah khususnya bidang studi matematika adalah mengikuti himbauan pemerintah untuk mengikuti pembelajaran daring dengan mengajak siswanya tetap belajar dari rumah masing-masing dengan cara yang paling memungkinkan dilakukan pada siswa madrasah Tsanawiyah yaitu mengikuti program televisi edukasi pada channel TVRI yang telah disediakan oleh menteri pendidikan. Berikutnya, apa alasan guru matematika mengambil langkah tersebut, adanya kondisi siswa Madrasah Tsanawiyah yang tidak memungkinkan dari sisi geografis dimana letak sekolah maupun rumah siswa berada dilingkungan pedesaan yang terkendala dengan sinyal internet dan fasilitas penunjang pembelajaran seperti HP dan laptop yang tidak semua siswa memiliki, ada siswa yang memiliki HP tetapi terkendala kuota, dan ada juga yang memiliki HP tetapi tidak support dengan beberapa aplikasi pendukung pembelajaran, misalnya Zoom, Google Meet dan lain sebagainya, maka guru 
matematika mengatakan bahwa langkah tersebut merupakan langkah yang tepat untuk diambil agar semua siswa bisa mengikutinya.

Cara untuk mengetahui siswa tetap mengikuti edukasi TVRI dari rumah, berdasarkan hasil wawancara dengan guru matematika bahwa siswa diminta untuk menonton serta memahami materi yang disampaikan pada channel televisi edukasi TVRI serta tetap belajar dari rumah masing-masing dengan pengawasan orang tua, dengan adanya pengawasan dari orang tua maka siswa tertib untuk mengumpulkan tugasnya, setiap ditayangkan soal matematika maka jawaban dikumpulkan kepada guru matematika dengan cara difoto lalu dikirim menggunakan WhatsApp secara pribadi, setelah semua siswa mengumpulkan maka guru matematika akan membahas materi dari whatsapp grup yang akan diikuti oleh semua siswa. Pengumpulan jawaban siswa paling lambat sore hari dihari yang sama dengan tayangan soal matematika mantul edukasi TVRI, disore hari guru akan membahas satu persatu dari soal yang telah dikumpulkan. Pembahasan dilakukan sore hari sebab sebagian siswa yang tidak memiliki HP bisa menggunakan HP anggota keluarga yang lainnya, dan menggunakan Whatsapp dalam pembahasan soal disebabkan tidak membutuhkan sinyal yang kuat dan kouta yang banyak, jika seluruh anggota keluarga tidak memiliki HP yang bisa digunakan untuk Whatsapp, siswa diminta untuk mengumpulkan ke sekolah langsung pada setiap hari Jumat jam 08.00 WIB.

Hasil observasi bahwa pembelajaran matematika pada jenjang SMP sederajat disebut matematika mantul "matematika manfaat betul" untuk pembelajaran matematika mantul pada jenjang SMP sederajat pada setiap hari selasa dan kamis, untuk siswa Madrasah Tsanawiyah diminta oleh guru bidang studi matematika untuk mengikuti pembelajaran program televisi edukasi dimulai pada hari Selasa tanggal 14 April 2020, penilaian yang diambil dalam penelitian ini selama satu bulan pada bulan April dengan 6 kali pengumpulan tugas matematika. Materi yang digunakan dalam penelitian ini meliputi perbandingan, teorema Phytagoras, aritmatika sosial, lingkaran, pecahan, dan bangun ruang sisi lengkung. Penyajian materi dari program televisi edukasi sangat menarik sehingga memberikan variasi siswa dalam belajar, penayangannya menggunakan contoh yang berkaitan dengan kehidupan sehari-hari lalu dilanjutkan dengan pemberian soal diakhir penayangan, dari soal yang ditayangkan maka siswa diminta menjawab dan menuliskan jawaban pada kertas untuk 
difoto lalu dikirim pada guru, dari beberapa penayangan soal matematika manfaat betul pada bulan April maka peneliti analisa ketuntasan belajar siswa pada setiap kali penayangan, sehingga pada bulan April terkumpul jawaban siswa sebanyak 6 kali pengiriman jawaban.

Dari hasil analisa bahwa nilai harian pertama pada tanggal 14 April 2020 dengan materi perbandingan siswa yang tidak tuntas sebanyak $8 \%$ sedangkan yang tuntas sebanyak 92\%, analisa nilai harian kedua pada tanggal 16 April 2020 dengan materi teorema Phytagoras siswa yang tidak tuntas sebanyak 12\% sedangkan yang tuntas 88\%, analisa nilai harian ketiga pada tanggal 21 April 2020 dengan materi aritmatika sosial siswa yang tidak tuntas sebanyak 12\% sedangkan yang tuntas sebanyak 88\%, analisa nilai harian keempat tanggal 23 April 2020 dengan materi lingkaran siswa yang tidak tuntas sebanyak $8 \%$ yang tuntas $92 \%$, analisa nilai harian kelima tanggal 28 April 2020 dengan materi pecahan siswa yang tidak tuntas $12 \%$ yang tuntas 88\%, analisa nilai harian keenam tanggal 30 April 2020 dengan materi bangun ruang sisi lengkung siswa yang tidak tuntas $16 \%$ sedangkan yang tuntas $84 \%$, persentase siswa yang tidak tuntas tiap penugasan selalu berubah-ubah selama bulan April. Sedangkan untuk rata-rata kelas pada penilaian pertama 76.96 pada penilaian kedua 76.92 pada penilaian ketiga 76.92 pada penilaian keempat 76.96 pada penilaian kelima 76.96 sedangkan penilaian ke enam 76,8. Sesuai wawancara 1 dengan guru matematika bahwa KKM $\geq 85 \%$ maka dari hasil analisa keenam penilaian siswa, hanya terdapat satu penilaian harian yang tidak mencapai KKM, dari hasil analisa, peneliti akan menggali pertanyan lebih lanjut dari guru.

Hasil wawancara 2 pada guru matematika, berdasarkan hasil analisa peneliti bahwa ketuntasan penilaian harian keenam tidak mencapai KKM disebabkan materi yang di tayangkan lebih sulit dari sebelumnya menurut pendapat siswa yaitu materi bangun ruang sisi lengkung. Berikutnya, langkah apa yang akan dilakukan oleh guru pada semester mendatang dalam pembelajaran daring, dimana guru akan memberikan tabungan sekolah siswa agar siswa dapat memenuhi kebutuhannya dalam menyediakan sarana pembelajaran daring yang sudah dihimbau oleh menteri pendidikan, dengan adanya bantuan kuota yang diberikan kepada siswa dan juga kepada guru, untuk memudahkan melakukan pembelajaran daring sehingga dapat meringankan beban guru dalam melakukan proses pembelajaran. 
Dari hasil penelitian yang dituangkan diatas bahwa keterbatasan HP dan laptob merupakan hambatan dalam pembelajaran daring begitu juga yang dikatakan oleh Masdafni (2020). Selain itu, ketuntasan belajar siswa akan tercapai sesuai standar KKM sekolah walaupun proses pembelajaran menggunakan daring, tergantung keuletan guru dalam menyampaikan materi dan menggunakan aplikasi yang mendukung. Beberapa hal yang terkait dengan tayangan program televisi edukasi TVRI belajar dari rumah salah satunya belum mewakili semua kurikulum matematika siswa kelas VIII maupun yang lainnya, masih menggabungkan semua kelas dengan tingkat tayangan televisi edukasi jenjang SMP sederajat. Oleh sebab itu adanya bantuan kuota bagi siswa dan guru, agar bisa menggunakan aplikasi yang lain untuk mencapai kurikulum yang telah ada.

\section{KESIMPULAN DAN SARAN}

Dari hasil penelitian bahwa pembelajaran yang dilakukan oleh guru matematika pada siswa Madrasah Tsanawiyah dengan mengikuti program pemerintah tetap belajar dari rumah dengan mengikuti televisi edukasi TVRI bahwa ketuntasan belajar siswa pada penilaian pertama sampai penilaian kelima sudah mencapai kriteria ketuntasan minimal, sedangkan pada penilaian keenam belum mencapai kriteria ketuntasan minimum. saran, untuk program televisi edukasi TVRI agar penayangan materi sekolah pada siswa setiap jenjang sesuai dengan kurikulum.

\section{REFERENSI}

Asmuni. 2020. Problematika Pembelajaran Daring di Masa Pandemi Covid-19 dan Solusi Pemecahannya. Jurnal Paedagogy : Jurnal Penelitian dan Pengembangan Pendidikan. 7(4). 281-288. Lombok Timur : IKIP Mataram

Masdafni. 2020. Pembelajaran Daring Menggunakan Video Animasi Meningkatkan Hasil Belajar Matematika Siswa Kelas VIIIC SMPN 1 Seberida. Jurnal Pendidikan Tambusai, 4(2), 1752-1763, Riau : Pendidikan Tambusai.

Menteri Kesehatan RI. Keputusan nomor HK.01.07/MENKES/413/2020. Tentang pedoman pencegahan dan Pengendalian Corona Virus Disease 2019 (Covid19). 
Menteri Pendidikan dan Kebudayaan RI. Surat Edaran Nomor 4 tahun 2020. Tentang Pelaksanaan Kebijakan Pendidikan Dalam Masa Darurat Penyebaran Corona Virus Disease (Covid-19).

Peraturan Pemerintah RI. Nomor 40 tahun 1991. Tentang Penanggulangan Wabah Penyakit Menular

Pratama L.D, Lestari W, Astutik I. 2020. Efektifitas Penggunaan Media Edutainment di Tengah Pandemi Covid-19. Aksioma : Jurnal Program Studi Pendidikan Matematika. 9 (2). 413-423. Universitas Muhammadiyah Metro.

Ratnawati, F.A. 2020. Strategi Meningkatkan Hasil Belajar Selama Pandemi Dengan Aplikasi Google Classroom Pada Materi Usaha Dan Energi. Ideguru:Jurnal Karya Ilmiah Guru. 5(1). 49-55.

Sugiyono. 2014. Metode Penelitian Kuantitatif Kualitatif dan R\&D. Bandung : Alfabeta

Wiryanto. 2020. Proses Pembelajaran Matematika Di Sekolah Dasar Di Tengah Pandemi Covid-19. Jurnal Review Pendidikan Dasar : Jurnal Kajian Pendidikan dan Hasil Penelitian. 6(2). 